UDK $630 * 37: 630 * 4$

\title{
DAMAGE ON STANDING TREES DURING WOOD SKIDDING (WINCHING PHASE) BY CABLE SKIDDER TIMBERJACK 225 A
}

\section{Oštećenja dubećih stabala u fazi primicanja drveta skiderom Timberjack} $225 \mathrm{~A}$

\section{Abstract}

Safet Gurda ${ }^{1}$, Jusuf Musić ${ }^{1}$, Dževada Sokolović ${ }^{1}$, Mahir Bašić ${ }^{2}$

Hauling of heavy and voluminous load (wood) partially through forest wastelands and partially on built roads makes this the most expensive phase, which is also technically the most challenging and most damaging for the forest eco-system. Although it is clear that the realisation of this phase in forest harvesting cannot be completed without certain forest damage, in expert and scientific circles there is general consent that by careful planning and execution in forestry, this damage can be brought down to an 'acceptable' level.

One of the reliable indicators of stand damage is the amount of mechanical damage resulting from forest harvesting operations. This damage can be ascertained rather easily and correctly, and the environmental and economic consequences of mechanical damage of standing trees are better known than those resulting from damaging saplings or the soil. (MARTINIĆ, 2000). Pertaining to this, this paper presents the measuring and analysis of mechanical damage to standing trees as a result of hauling trees using the cable skidder 'Timberjack 225 A' in the forest unit 17, Management Unit 'Gornja Stavnja', Forest Management Company 'Gornjebosansko'. The amount of damage was analysed, the place where it occurred on the tree, the level of damage and the surface of the inflicted damage. All the stated analyses were carried out for two ways of skidding wood using a winch (falling and ascending).

Results show, among others, that the stand damage expressed in the percentage of damaged trees of the total tree count is $15.41 \%$, which is the upper limit MARTINIĆ (1993) ascertained for this phase of forest harvesting, including the variability of working methods and techniques. Almost half of the damage is stated in the first third of the distance between the skidder path and transport boundary, with the largest amount of damage occurring on the most valuable part of the tree (butt end), especially during slope skidding.

Key words: forest harvesting, wood skidding, tree damage

\footnotetext{
${ }^{1}$ Faculty of Forestry, University of Sarajevo

${ }^{2}$ Public enterprise "Šumsko-privredno društvo Zeničko-dobojskog kantona" d.o.o., Zavidovići
} 


\section{INTRODUCTION - Uvod}

A more significant mechanisation in tree skidding operation in these areas starts in the 60s of the last century. The objective and sensible reasons for introducing machines in the production process are: (1) greater work productivity, (2) lowering production unit costs and (3) humanization of hard forest labour. Nonetheless, it soon became clear that every application of machines in forests most certainly has specific negative consequences on the forest eco-system (emission of harmful matter, stamping on and compressing soil, damaging young and standing trees etc.) Raising environmental awareness and the more prominent and radical requests for conserving the environment resulted in the introduction of the environmental indicator and an important milestone in assessing machines and work procedures. As early as the 1980s, there had been warnings about how the continued usage of new technology and machines in forests had to be considered in line with potentially negative environmental consequences and be compared to economic indicators (MATIĆ, 1983). Pertaining to that when considering economy in forestry, the new attitude is to take in consideration, above all, the maximum protection of forest eco-systems and the obligatory application of environmentally friendly work technology (GLAZAR AND MACIEJEWSKA, 2009). Machines with environmentally acceptable indicators are referred to as environmentally friendly or nature closely (MARTINIĆ, 2000) in foreign expert literature.

Therefore, the task of foresters experts are selection of environmentally friendly technologies and machines for forestry operations and monitoring of direct and indirect damages all components of the forest ecosystem (PičMAN ET AL., 2003).

The negative effects of machines on the forest eco-system have been the subject of numerous and constant research, often with different results as well as conclusions regarding the necessary measures for the reduction of machine usage. This is primarily due to different research methodologies, as well as evident heterogeneity of means and techniques of work field and stand conditions, manner of caring for and renewing stands management systems etc. However, among authors who dwelt on the issue of forest damage, there is general agreement that due to the nature of work, work operations on forest harvesting cannot be carried out without a certain amount of damage to the forest eco-system despite the implemented protection measures. The prevailing opinion is also that the choice of proper means of work, good organisation of work, the application of work methods and techniques according to field and stand conditions, as well as the appropriate motivation of forest workers, may bring negative consequences down to a minimum, i.e. an 'acceptable' level.

Most researchers are of the opinion that the number of mechanically damaged trees is a good indicator of the total amount of stand damage (TOMANIĆ ET AL., 1989, ReISINGER AND POPE, 1991, ATHANASSIAdIS 1997, SIRÉN 2001). This damage can be ascertained rather easily and correctly, and the environmental and 
economic effects of mechanical damage to standing trees are better known than those in damaging young trees or the soil (MARTINIĆ, 2000). Apart from the negative effect on the growth of standing trees (ISOMAKI AND KALLIO, 1974; KRPAN ET AL., 1993), and the degraded quality of cut but damaged trees (VANDERBERG, 2002), the most important aspect of mechanical damage is the actual possibility of infection by wood-decay fungus. The appearance of wood-decay fungi and their development depend on the size and age of the damage, tree type, time and place of damage (VASILIAUSKAS, 2001), while the possibility of infection is lower in the case of squashed bark than peeled tree bark (LIMBECK-LILIENAU, 2003).

Every damaged standing tree does not necessarily mean the lack of worth. Although the literature does not precisely state which surface or size influence the damaged standing tree and to which effect (PORŠINSKY I OžURA, 2006), there is substantial knowledge, for us the most important being about the current climate and stand conditions. In the breeding-technical classification of trees of our most important tree types, MATIĆ ET AL (1971) specify the width of the damage at $10 \mathrm{~cm}$ as critical i.e. the one which classifies beech, fir and spruce trees in the third quality class. Pines are allowed to have somewhat larger damage in the range from 10 to $20 \mathrm{~cm}$ depending on the type and diameter.

Three years after conducting recording of standing tree damage caused during skidding using cable skidder KRPAN ET AL. (1993) determined fertile fungi and the destruction of sapwood on a quarter of damaged oak trees. They determined that the infection of the trees and the fostering of decay depended on the size of the damage and its position on the tree. The development of mycosis was not determined on damaged surfaces smaller than $100 \mathrm{~cm}^{2}$ and they believe that a tree can heal such damage. DANiLOVić ET AL. (2015) analyzed of damage to residual trees and the regeneration that occurs during harvesting using the half tree length method and timber extraction in winter operating conditions in a pure beech stand and a mixed stand of beech fir and spruce. They reached the following conclusions: a) the largest share of damage to residual trees during felling in both stands is to the crowns of neighbouring trees; b) during the timber winching the most common type of damage in both stands incurred is to the root collar, c) at the stage of timber skidding the largest number of wounds in both cases was to the butt end of trees along the skid trail. Evident damages to the regeneration found in both phase (felling and transport) but due to a higher density of seedlingsis the damages are significantly higher in the mixed stand than in the pure stand. Authors found that during tree felling in both stands, the most common wounds are the ones whose area is greater than $200 \mathrm{~cm}^{2}$, whereas in the phase of transport of wood assortments the most common wound areas range from 50 to $200 \mathrm{~cm}^{2}$.

Unfortunately, this very important and complex issue has not been given enough attention in $\mathrm{BiH}$ forestry and science. Having the recognized multiple negative importance of forest damage to start with, a couple of papers dealing with this issue (LOJO I MUSIĆ, 2006, KRIŠTO, 2012; VESELINOVIĆ, 2012) are an 
insufficient number, to say the least. There lies the need and motive for this specific research.

\section{AIM AND METHOD OF THE RESEARCH - Cilj i metod istraživanja}

Based on the analysis of relevant literary sources on the issue of forest damage and practical experience, KULUŠIć (2000) concludes that the largest amount of damage occurs in the tree skidding phase where trees on the edge take most damage. In the tree skidding phase, the most threatened are standing trees located in the first third of the distance between the skidder path and transport boundary. Tree skidding represents the transport of wood from the stump to the skidder path i.e. secondary forest communication. In accordance, the aims of the research are:

- determine the total damage of standing trees during skidding,

- determine stand damage expressed in percentage of damaged trees compared to the remaining number of trees after felling,

- analyse the structural features of the damaged which occurred,

- define measures for lowering the amount of standing tree damage.

The record of the damage which occurred was conducted on two research fields, each $2.700 \mathrm{~m}^{2}$. The fields are arranged vertically to the direction of the skidder path, with one below the path (slope skidding), and the other above the path (downfall skidding). Field and stand circumstances did not stipulate the setting of the planes. The fields are divided into three zones, 900 $\mathrm{m}^{2}$ each with intervals and markings as presented in Table 1.

Table 1. Basic features of the research fields

Tabela 1. Osnovne karakteristike oglednih ploha

\begin{tabular}{|c|c|c|}
\hline Position & Mark & Distance from the skidder path $(\mathrm{m})$ \\
\hline \multirow{2}{*}{$\begin{array}{c}\text { Above the skidder path }- \\
\text { Field 1 }\end{array}$} & $\mathrm{P}_{1}$ & $0-30$ \\
\cline { 2 - 3 } & $\mathrm{P}_{2}$ & $31-60$ \\
\cline { 2 - 3 } & $\mathrm{P}_{3}$ & $61-90$ \\
\hline \multirow{2}{*}{$\begin{array}{c}\text { Below the skidder path }- \\
\text { Field 2 }\end{array}$} & $\mathrm{U}_{1}$ & $0-30$ \\
\cline { 2 - 3 } & $\mathrm{U}_{2}$ & $31-60$ \\
\cline { 2 - 3 } & $\mathrm{U}_{3}$ & $61-90$ \\
\hline
\end{tabular}

The damage was recorded after the conducted forest harvesting operations. This enabled unobstructed work and excluded their subjectiveness in a way of being more careful while working on the fields. For the purpose of damage analysis the following data was recorded:

- number of damaged trees,

- the distance of the damaged tree from the skidder path according to Table 1 ,

- the position of damage (Figures 1 and 2),

- the degree of damage (I - squashed bark; II - debarked tree ; III debarked and damage tree-Figure 3), 
Damage on standing trees during wood skidding (winching phase) by cable skidder Timberjack $225 \mathrm{~A}$

- the size of the damage in $\mathrm{cm}^{2}$ (by measuring the height and width or diameter of injuries depending on its shape).
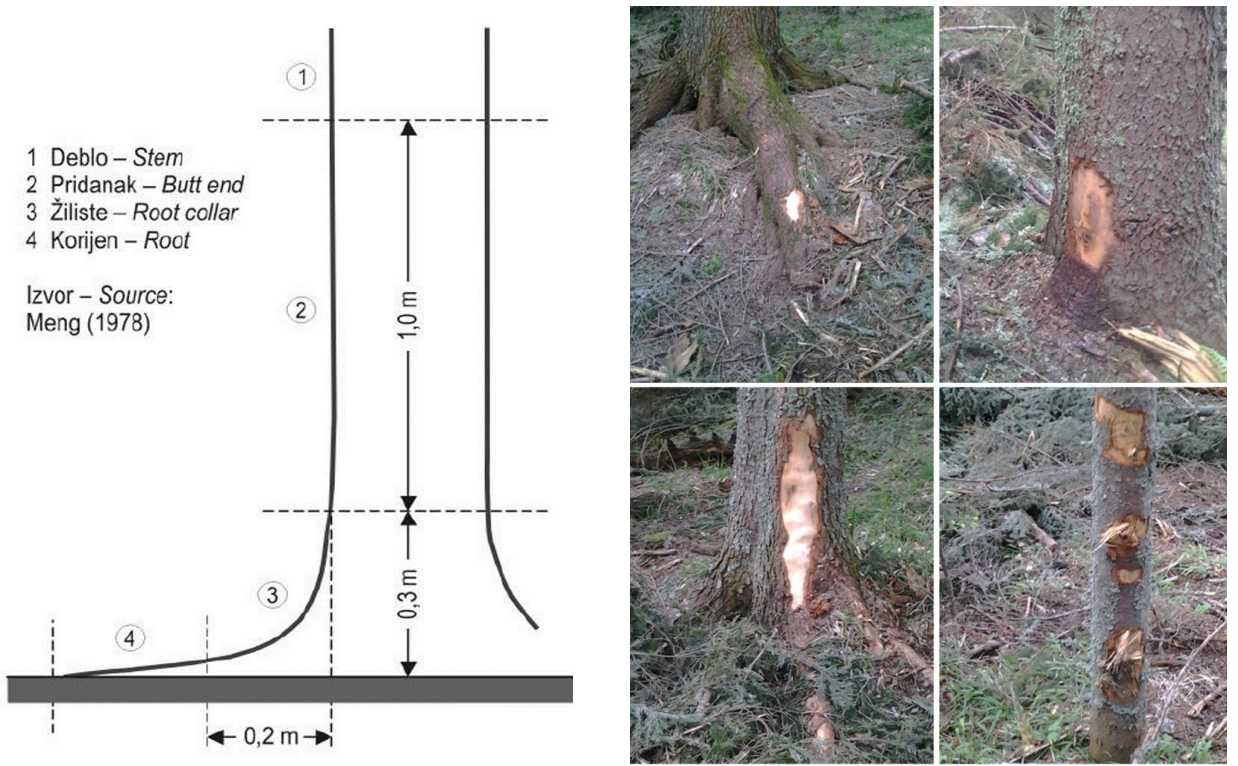

Figure 1. Classifying the position of tree damage Figure 2. The position of tree damage

Slika 1. Klasifikacija mjesta oštećenja stabla

Slika 2. Mjesto oštećenja stabla

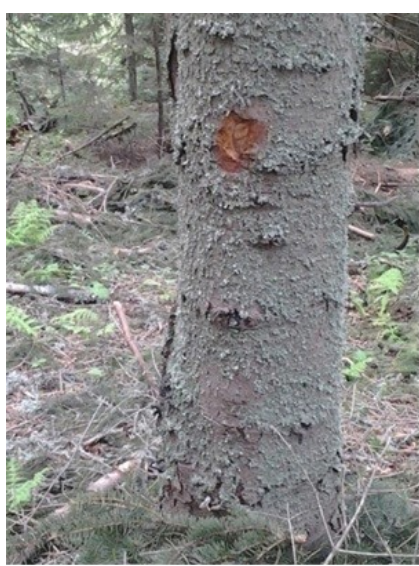

I) Squashed bark

I) Nagnječena kora

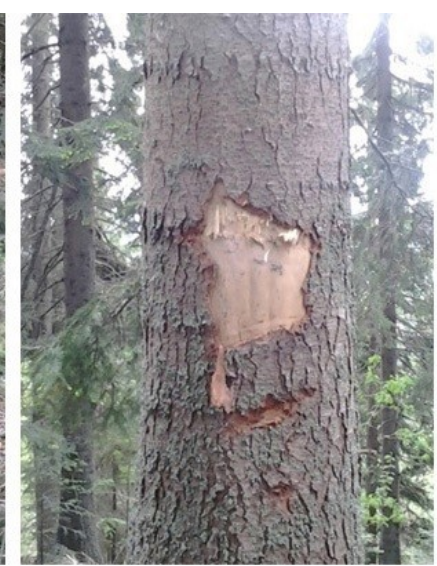

II ) Debarked tree

II) Oguljena kora

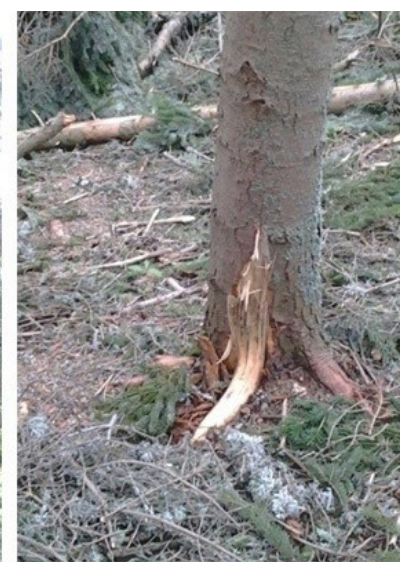

III) Debarked and damaged tree

III) Oguljena kora i oštećeno drve

Figure 3. Classifying standing trees according to the level of damage

Slika 3. Klasifikacija dubećih stabala prema stepenu oštećenja 


\section{PLACE OF RESEARCH - Mjesto istraživanja}

The research was conducted in the mixed stand of beech and fir with spruce, forest unit 17, Management Unit 'Gornja Stavnja', Forest Management Area 'Gornjebosansko'. The area of the unit is 75.30 ha, of south-eastern exposition with an average slope of 20-35 degrees. The unit is located on 1000 to $1300 \mathrm{~m}$ altitude. The satellite image of the wider area and the sketch of the unit with the inserted position of the secondary communication network are presented in Figures 4 and 5.

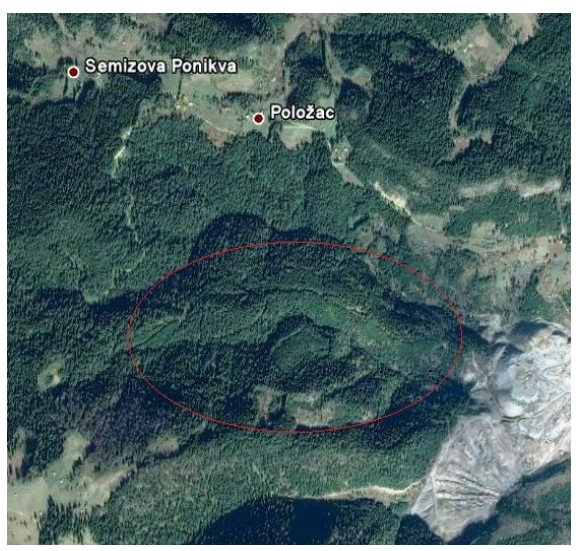

Figure 4. Satelite image of the wider area Slika 4. Satelitski snimak šireg područja

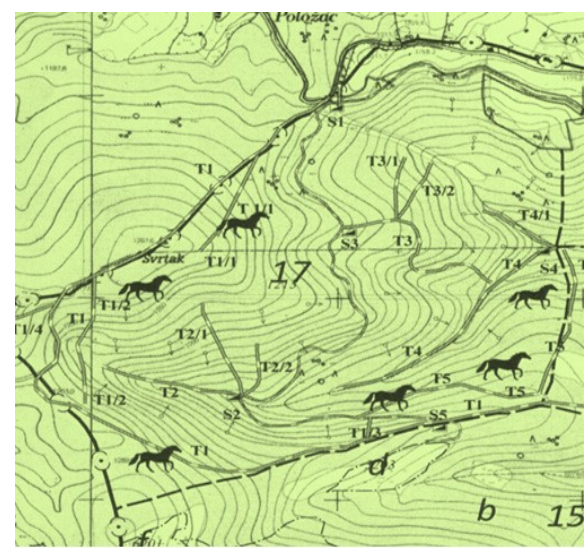

Figure 5. Sketch of the forest unit 17 Slika 5. Skica šumskog odjeljenja 17

The volume of large wood before felling was $370,36 \mathrm{~m}^{3} / \mathrm{ha}$. The shares of species in the stand as follows: $62 \%$ fir, $34 \%$ spruce, 3 beech and other broadleaved species $1 \%$. The intensity of felling was $19.68 \%$, with the average mass of the average cut tree being $1.4 \mathrm{~m}^{3}$. Trees are felled, delimbed and bucked to various assortments directly in the stump area (Cut-to-length method). Length of assortments ranged from 4 to 6 meters.

A detailed design for this unit foresees wood skidding to be carried out by cable skidder 'Timberjack 225 A'. Part of the wood mass that cannot be hauled by the skidder, due to the length limitation of the cable, will be hauled to the skidder path by horses (about $10 \%$ ). Total length of skidder paths is 4,710 metres, which gives the average openness of the unit at 62.5 $\mathrm{m} / \mathrm{ha}$. The average slope of skidder paths in the unit is around $25 \%$.

The felling of trees and extraction of logs was carried out in June 2014. All data were collected immediately after the work was completed.

\section{RESULTS AND DISCUSSION - Rezultati i diskusija}

Following the recording and registering of data in June 2014, data analysis was conducted in line with the defined work methods.

The total amount of damage on both fields was 60 . There were 36 registered damage at 26 damaged trees on field 1 . The amount and 
distribution of damage and damaged trees on defined fields depending on the distance regarding to the skidder path are shown in Figure 6.

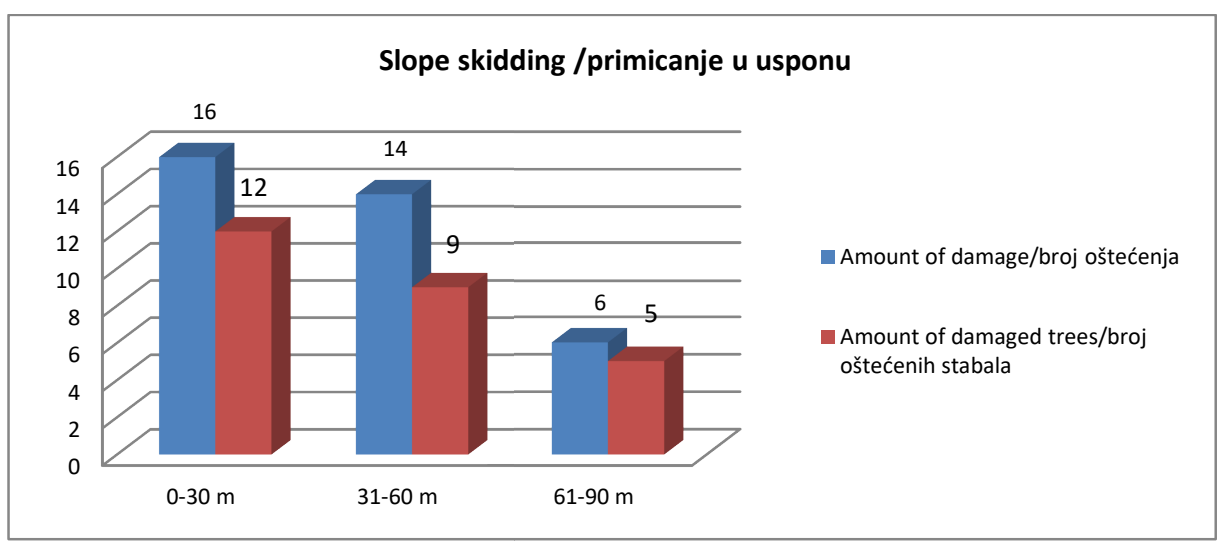

Figure 6. Amount and distribution of damage and damaged trees on field 1 Slika 6. Broj i distribucija oštećenja i oštećenih stabala na plohi 1

The average amount of damage on damaged trees is 1.38 which means that some trees were damaged in two places. In the first area there were 4 of these trees, five in the second, and only one such tree in the third area.

There were 24 instances of damage on 17 different trees registered on research field 2. The amount and distribution of damage and damaged trees on this field are presented on Figure 7. This field also registered double damaging on some trees; 3 trees in the first, 4 trees in the second and no trees in the third area. The average amount of damage per damaged tree was somewhat larger -1.41 .

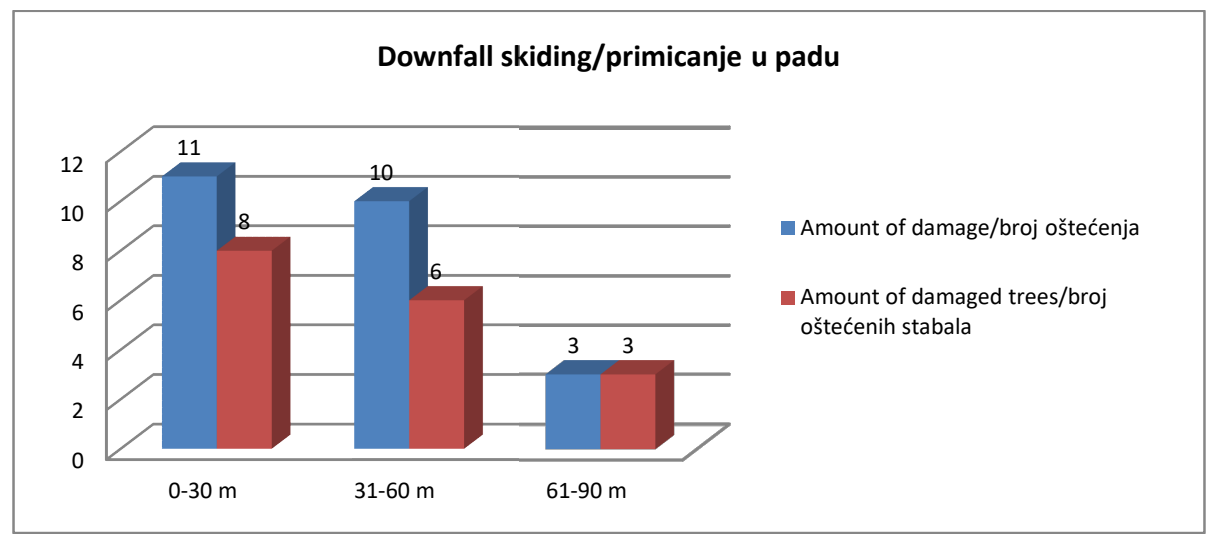

Figure 7. Amount and distribution of damage and damaged trees on field 2 Slika 7. Broj i distribucija oštećenja i oštećenih stabala na plohi 2 
The presented results confirm the thesis that the most endangered standing trees in the skidding phase are located in the first third of the distance between the skidder path and transport boundary (KULUŠIć, 2000). Based on the presented figures, it can be noticed that the largest amount of damage and damaged trees on both fields is in this area $(0-30 \mathrm{~m})$, with a somewhat fewer number of damaged trees on field 2 .

The total amount of damaged trees and damage in this area for both fields is almost half. What is worrying is the double amount of damage on some trees which was registered on both fields, and is a result of utter carelessness during work operations.

The largest amount of damage on field 1 was registered at a height between 0.3 and $1.3 \mathrm{~m}$, with a total of 19 or $52.8 \%$; followed by 7 instances of damage or $19.4 \%$ at the height of 0 to $30 \mathrm{~cm}$. There were 6 instances of damage on the root $(16.7 \%)$, while the smallest number of damage was at the height of over $1.30 \mathrm{~m}-4$ instances of damage or $11.1 \%$.

The largest amount of damage on field 2 occurred at a height of 0 to $0.3 \mathrm{~m}-12$ instances of damage, or $50 \%$. At a height of 0.3 to $1.3 \mathrm{~m}$, there were 8 instances of damage or $33.33 \%$, while the remaining 4 instances of damage were recorded on the root and comprise $16.66 \%$. Injuries or instances of damage, at a height over $1.3 \mathrm{~m}$ were not recorded on this field. The distribution of damage according to the place of origin on the tree according to MENG (1978) is presented in Figure 8.
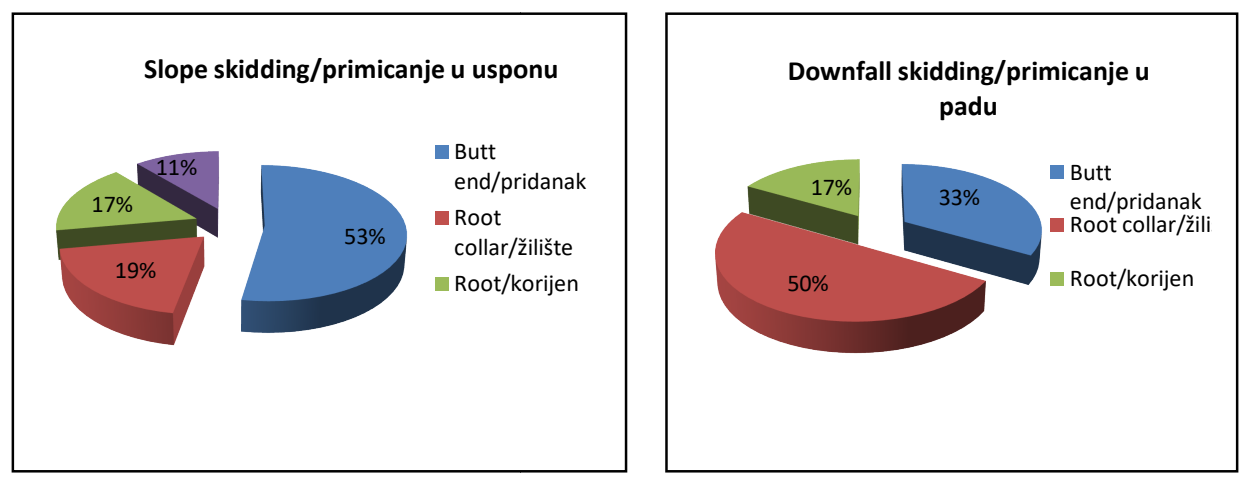

Figure 8. Damage according to place of origin in percentages (field 1 and 2)

Slika 8. Oštećenja po mjestu nastanka u procentima (plohe 1 i 2)

Based on the presented figure, it is evident that the largest amount of damage occurred on the most valuable part of the tree (butt end). The total amount of butt end damage for both fields is $45 \%$. Apart from the butt end, there was substantial damage to the most sensitive parts of the tree (root collar and root), especially on field 2 (The noted differences in these two fields is the slope i.e. slight rise of the load during slope skidding, and therefore damaging standing trees at a greater height. 
In accordance with the applied work method on the research fields, the degree of damage to the trees was also marked, and the distribution of damage according to the defined degree is presented in Figure 9.

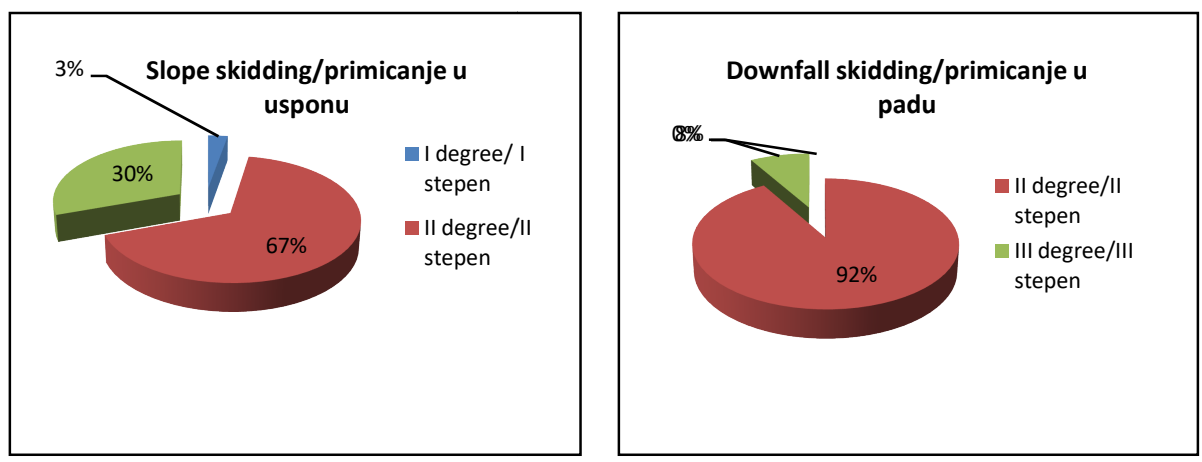

Figure 9. Damage according to degrees in percentages (fields 1 and 2)

Slika 9. Oštećenja po stepenima u procentima (plohe 1 i 2)

The most common degree of damage on research field 1 is debarking without damage to the tree $\left(2^{\text {nd }}\right.$ degree $)-24$ instances of $66.66 \%$ of the total number of damage. It is followed by $3^{\text {rd }}$ degree of damage (debarking and damaged tree) with 11 instances or $30.55 \%$, while damage of the $3^{\text {rd }}$ degree (squashed bark) was noticed only once, which represents $2.77 \%$ of total damage.

There was no $1^{\text {st }}$ degree damage on research field 2; but the largest amount was of $2^{\text {nd }}$ degree -22 instances or $92 \%$, with $8 \% 3^{\text {rd }}$ degree damage. It can be concluded that $2^{\text {nd }}$ degree damage is dominant, i.e. debarking. The share of this type of damage of both fields is $77 \%$.

The total surface of tree damage on research field 1 was $2,940 \mathrm{~cm}^{2}$, and $1,564 \mathrm{~cm}^{2}$ on field 2. Although the amount of damage on field 1 was $50 \%$ larger than on field 2 , the total surface of damage is larger by $88 \%$. The average surface of damage on field 1 is thus $81.66 \mathrm{~cm}^{2}$ and $65.16 \mathrm{~cm}^{2}$ on field 2. The largest registered instance of damage was on field $1-380 \mathrm{~cm}^{2}$, and 230 $\mathrm{cm}^{2}$ on field 2 .

The average damaged surfaces on the research fields depending on the distance of damaged trees from the skidder path are presented on Figure 10. 


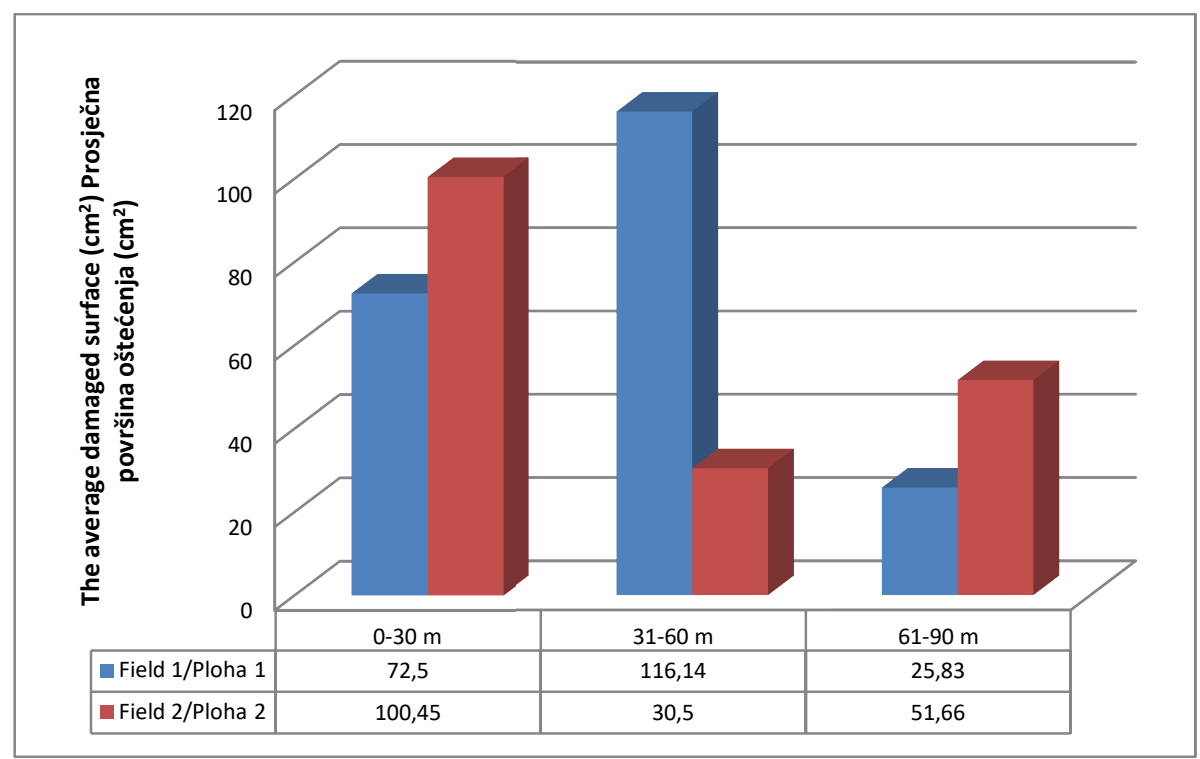

Figure 10. Average damaged surface on the set fields $\left(\mathrm{cm}^{2}\right)$

Slika 10. Prosječne površina oštećenja na postavljenim plohama $\left(\mathrm{cm}^{2}\right)$

Considering that the percentage of damaged trees in relation with the total number of trees in the stand is a reliable indicator of the degree of stand damage, this paper presents this calculation as well. The total number of remaining trees after the conducted felling for both fields is 279 . Since there were 43 damaged trees, this makes the stand intensity damage of $15.41 \%$, which is $18.8 \%$ for field 1 and $12.1 \%$ for field 2 .

How large the intensity of the damage is, is best illustrated by the fact that for similar conditions, methods and means of work SABO (2003) determined the damage intensity from $1.77 \%$ (object B) to $1.84 \%$ (object A). Nonetheless, it is important to highlight that the average surface of damage this author determined was multiple times larger.

Figure 11 presents the damage intensity of stand in percentage on research fields depending on the distance of the trees from the skidder path. 


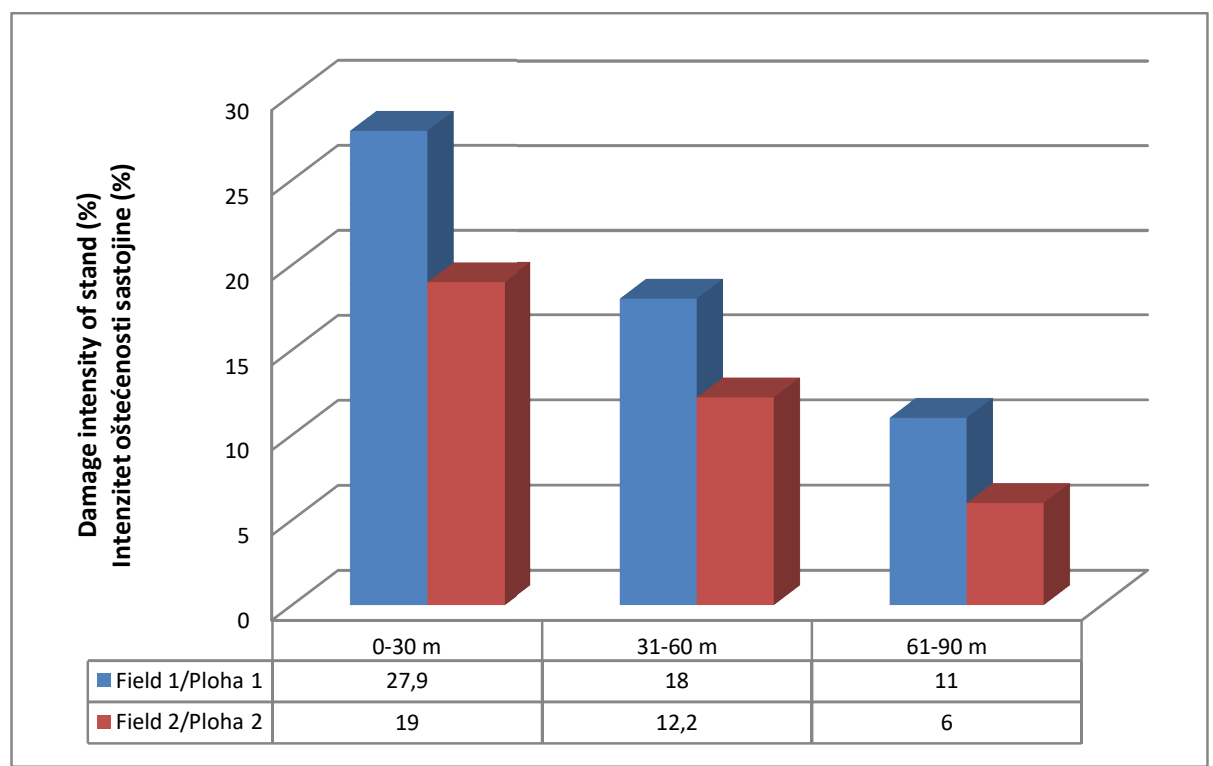

Figure 11. Damage intensity of stand in percentage

Slika 11. Intenzitet oštećenosti sastojine u procentima

\section{CONCLUSIONS - Zaključci}

Based on the results, which have been thoroughly presented and explained in the paper, the following more important conclusions can be highlighted:

1. Stand damage expressed in the percentage of damaged trees in the total tree count is a staggering $15.41 \%$ which is the upper limit MARTINIC (1993), ascertained for this phase of forest exploitation, including the variability of work methods and techniques.

2. Almost half of all damage was noticed in the first third of the distance between the skidder path and transport boundary with intolerably double or multiple damage to specific trees.

3. The largest number of damage occurred on the most valuable part of the tree (butt end), especially during slope skidding.

4. The only ,positive“ aspect to be highlighted is that the level of tree damage is not high, i.e. the predominant type of damage is debarking with an average damaged surface of approximately $70 \mathrm{~cm}^{2}$ which is categorised as insignificant damage which the tree can heal, according to KRPAN ET AL. (1993).

5. With the aim of decreasing the damage on standing trees, young trees and soil, planning of optimal secondary forest road network must include ecologic criteria including the plan of physical protection most endangered trees. Also, it is necessary to pass a suitable rulebook that 
shall regulate mandatory and consistent application of technological forest classification when creating forest management bases and detailed designs.

6. The current valorisation of the effects of work of certain means used in skidding wood only from the aspect of work effects is completely wrong and unsustainable in the future, and it is thus necessary to include environmental and ergonomic parameters alongside economic ones. Therefore, there is an urgent need to create an appropriate model of forest damage estimation.

\section{REFERENCES - Literatura:}

AtHANASSIADis, D. (1997): Residual stand damage following cut-to-length harvesting operations with a farm tractor in two conifer stands. Silva Fennica 31(4): 461- 467.

GlazAR, K. AND MACIEJEWSKA, M. (2009): Ecological aspect of wood harvesting amd skidding in pine stands with use different technologies. Acta Sci. Pol. Silv. Colendar. Rat. Ind. Lignar. 8(3), pp. 5-14.

Danilović M., Kosovski M., Gačić D., Stojnić D., Antonić S. (2015). Damage to residual trees and regeneration during felling and timber extraction in mixed and pure beech stand. Šumarski list. 5-6:253-262.

ISOMAKI, A. AND KALLIO, T. (1974): Consequences of injury caused by timber harvesting machines on the growth and decay of spruce (Picea abies (L) Karst.) Acta For. Fenn. 136, 1-25.

KRIŠTO, R. ( 2012): Analiza oštećenja sastojine koja nastaju pri primicanju i privlačenju drveta. Diplomski rad. Šumarski fakultet u Sarajevu.

KRPAN, A. P. B., Petreš, S., IVANović, Ž: (1993): Neke fizičke štete u sastojini, posljedice i zaštita (Forest stand damage,effects and protection). Glasnik za šumske pokuse, Posebno izdanje, 4: 271-279.

KULUŠıć, B. (2000): Manuskript - Iskorišćavanje šuma. Šumarski fakultet u Sarajevu.

LimBECK-LiLienAU, B. (2003): Residual stand damage caused by mechanized harvesting systems. In: Proceedings of the Austro2003 meeting: High Tech Forest Operations for Mountainous Terrain. CD ROM. LimbeckLilienau, Steinmüller and Stampfer (editors). October 5-9, 2003, Schlaeg1 - Austria. 11 p.

LoJo, A. I Musıć, J. (2006): Vrste i brojnost oštećenja stabala jele (Abies alba Mill.) u šumama bukve i jele sa smrčom. III Simpozijum o zaštiti bilja u BiH. Neum, 13.-15. decembar 2006. Zbornik rezimea, str. 52-53.

Matić, V., Drinić, P., Stefanović,V., ĆiRić, M. I SARAdNici (1971): Stanje šuma u Bosni i Hercegovini prema inventuri šuma na velikim površinama $u$ 1964-1968. godini. Šumarski fakultet i Institut za šumarstvo. Posebna izdanja, broj 7. Sarajevo.

MATić, S. (1983): Šuma i mehanizacija. Zbornik savjetovanja "Šumarska mehanizacija u teoriji i praksi" Opatija, 1983, str. 37-46. 
MARTiNić, I. (1993): Neke činjenice u svezi sa šumskim radovima. Glas. šum. pokuse, posebno izdanje 4, 321-330.

MARTinić, I. (2000): Koliko smo blizu ekološki prihvatljivoj uporabi mehanizacije u šumarstvu? Šumarski list br. 1-2, CXXIV, str. 3-13.

MENG, W., (1978): Baumverletzungen durch Transportvorgänge bei der Holzernte - Ausmaß und Verteilung, Folgeschäden am Holz und Versuch ihrer Bewertung. Schriftenreihe der LFV Baden-Württemberg, Band 53, 159 str.

Pičman, D., Pentek, T., PoRšinsky, T. (2003): Prilog istraživanju oštećivanja stabala mehanizacijom za gradnju šumskih putova. Strojarstvo 45(4-6): 149-157.

PORŠinSKY, T., OžURA, M. (2006): Oštećivanje dubećih stabala pri izvoženju drva forvarderom. Nova mehanizacija šumarstva. Vol. 27., str. 41-49.

Reisinger, T.W. AND POPE, P.E. (1991): Impact of timber harvesting on residual trees in a central hardwood forest in Indiana. Proceedings 8th Central Hardwood Forest Conference. University Park, Pennsylvania. March 4-6, 1991.

SABO, A. (2003): Oštećivanje stabala pri privlačenju drva zglobnim traktorom TIMBERJACK $240 \mathrm{C}$ u prebornim sastojinama. Šumarski list 7 -8, str. 335-348.

SIRÉN, M. (2001): Tree Damage in Single-Grip Harvester Thinning Operations. Journal of Forest Engineering. Vol 12, No. 1, 29-38.

TOMANić, S., VondRA, V., MARTINIĆ, I. (1989): Oštećivanje sastojine pri šumskim radovima. Mehanizacija šumarstva, 14, br. 3 - 4, 65-72, Zagreb.

VANDERBERG, M. R. (2002): Harvested log damage and value loss associated with two ground-based harvesting system in Central Appalachia. Master thesis. Davis College of Agriculture, Forestry, and Consumer Sciences at West Virginia University.

VASILIAUSKAS R. (2001): Damage to trees due to forestry operations and its pathological significance in temperate forest: a literature review. Forestry, 74: 319-336.

VESELINOVIĆ, T. (2012): Mehanička oštećenja dubećih stabala i podmlatka kao posljedica radnih operacija iskorišćavanja šuma na području ŠGP „Igmansko". Završni rad. Šumarski fakultet u Sarajevu.

\section{SAŽETAK}

Mehanizacija radova na privlačenja drveta uz sve benefite koji se, između ostalog, ogledaju u povećanju produktivnosti rada, smanjenju jediničnih troškova i humanizaciji teškog šumskog rada neminovno uzrokuje veća ili manja oštećenja na preostalim stablima, podmlatku i zemljištu. Vrsta, brojnost i veličina oštećenja zavise od niza faktora: dužine sortimenata, načina privlačenja, sezone rada, nagiba terena, metode iskorištavanja šuma, uvježbanosti rukovatelja, gustine primarne i sekundarne mreže puteva i dr. Cilj ovoga rada je utvrđivanje broja i veličine oštećenja na preostalim 86 
stablima u mješovitoj sastojini bukve i jele sa smrčom pri primjeni sortimentnog metoda rada. Pored toga, u radu je izvršena analiza strukturnih obilježja nastalih oštećenja i definisane neke mjere za njihovo smanjenje.

Istraživanje je provedeno u šumskom odjeljenju 17, GJ "Gornja Stavnja", ŠGP „Gornjebosansko“, juna 2014. god., na dvije ogledne plohe veličine $2.700 \mathrm{~m}^{2}$. Sječa stabala i izrada drvnih sortimenata izvršena je motornom pilom, a primicanje i privlačenje izrađenih sortimenata skiderom Timberjack 225 A“ sa ugrađenim vitlom.

Rezulati su, između ostalog, pokazali da oštećenost sastojine izražena procentualnim udjelom oštećenih stabala u ukupnom broju stabala iznosi čak 15,41\% što predstavlja gornju granicu koju je MARTINIć (1993), uz uključenu varijabilnost metoda i tehnika rada, utvrdio za ovu fazu rada iskorištavanja šuma. Skoro polovina svih oštećenja zabilježena je u prvoj trećini udaljenosti između traktorskog puta i transportne granice, pri čemu se najveći broj uštećenja desio na najvrednijem dijelu stabla (pridanku), pogotovo kada je primicanje vršeno uz padinu. U pogledu stepena oštećenih stabala dominiraju oštećenja skinute kore sa prosječnom površinom ozljede od oko $70 \mathrm{~cm}^{2}$ što se svrstava u kategoriju neznatnih oštećenja koja, prema navodima KRPANA I DR. (1993), stablo može sanirati.

Plan optimalne mreže sekundarnih šumskih komunikacija mora pored ekonomskog uvažavati i ekološki kriterij, uključivo plan fizičke zaštite najugroženijih stabala na linijama primicanja i privlačenja drveta. Pored toga, u cilju smanjivanja oštećenja dubećih stabala, podmlatka i šumskog tla neophodno je što prije odgovarajućim pravilnikom propisati obaveznu i

dosljednu primjenu tehnološke klasifikacije šuma pri izradu šumskogospodarskih osnova i izvedbenih projekata.

Corresponding author: Safet Gurda; Faculty of Forestry University of Sarajevo, Zagrebačka 20, 71000 Sarajevo, Bosnia\&Herzegovina; e-mail:. s.gurda@sfsa.unsa.ba 